\title{
Agricultural development-led industrialization strategy in Ethiopia: An overview
}

\author{
Akhilesh Chandra Prabhakar* and Yinges Alemu \\ Department of Economics, FBE, University of Gondar, P.O.Box 271, Gondar, Ethiopia. \\ Accepted 31 May, 2013
}

\begin{abstract}
This paper assesses the recent policy reforms. The result shows that there is no evidence that the poverty situation has improved. Most individuals and government officials have said there are political, socio-economic and nation-building achievements in the successful completion of 19 years (1991-2010) EPRDF-led govt. They claim remarkable progresses have been made in the areas of economic growth, employment, poverty alleviation, health, peace, democracy, paving the way for prosperous Ethiopia. The opponents of the EPRDF claim that under the Derg and the EPRDF regimes, the performance of agriculture and the economy has been disappointing over the last three decades. They have failed to resolve economic crisis, mass poverty, illiteracy and unemployment problems. The EPRDF is ready to face the general election on May $23^{\text {rd }}, 2010$ after successfully completion of the government led by the Prime Minister, Mr. Meles Zenawi for 19 years. It is a right time to review the regime of the EPRDF. Lastly, there is an attempt to get an alternative approach to the development of the Ethiopian society.
\end{abstract}

Key words: Agricultural development, industrialization, strategy, Ethiopia.

\section{INTRODUCTION}

The $83 \%$ of the Ethiopian people dwelling in the rural areas do not have the leverage of choosing to neglect agriculture. Agriculture sector would not have a significant impact on economic growth. Pervasive poverty is manifested in the highest incidence of malnutrition and food insecurity. It is estimated that $64 \%$ of children under the age of 5 are stunted and with little chance of "catch up' growth as they become older. Both chronic and transitory problems of food insecurity are severe in Ethiopia (Devereux, 2010). High rates of unemployment in urban areas and shortage of land in rural areas, where one-third of the households farm less than 0.5 ha are the major causes of chronic food insecurity. Inflation has jumped to $150 \%$ in March 2010 because of declining exports sectors and rising imports, depreciating Birr and fall in aid and foreign direct investments. The $85 \%$ people of the total population are still living in a continuous risk of food shortage, and their life is seriously related to external help. In most of the areas, attempts are made to stimulate and facilitate reforestation and horticulture productions; there is focus on the implementation of irrigation schemes with new land deals for the production of meat, cereals, fruits and seeds. But these attempts are not able to solve the basic problems of the ordinary people.

\section{Objectives of the study}

The central objective of the study is, therefore, to examine an inter-relationship between growth and exploittation, employment and poverty, food crisis and inflation in the Ethiopian context. The specific objectives of the study are to:

*Corresponding author. E-mail: acpjnu@yahoo.co.in. Tel: 00251-918-150124. 
1. Examine the trends of agriculture output, employment and social scene in Ethiopia.

2. Decompose the impact of growth into employment, productivity and multiple effects.

3. Quantify the impacts of alternative public policies on employment and poverty.

4. Suggest an alternative approach to the development and policy recommendations.

\section{METHODOLOGY}

The study is mainly based on a review of previous research. The data have come from various sources including NIAS, household surveys of Economics of Addis Ababa University. In addition, interviews and group discussion with various sections of society have been used to bridge gaps in information obtained from primary/ secondary sources.

\section{THE POLITICAL ECONOMY OF ECONOMIC REFORMS IN ETHIOPIA (1991-2010)}

The Political Economy of Reforms in Ethiopia 1991-2010, the EPRDF-led government has introduced several measures, some of which are listed as follows:

1. The Birr was devaluated by $58.6 \%$ in US dollar terms;

2. An auction system was introduced to determine the exchange rate applicable to most transactions;

3. Procedures for export and import licensing were streamlined;

4. New interest rate structure was introduced and new rates of interest maintained;

5. A number of tax policy reforms and government revenue enhancement measures were introduced;

6. Public expenditure was rationalized; public sector salaries were adjusted upwards and ceilings on public salaries were removed;

7. The first public enterprises were sold;

8. New investment, labour and public enterprises laws were enacted;

9. Direct price controls were virtually eliminated, and internal marketing, transport, and trade were decontrolled;

10. In the external area, restrictions on payments for invisible transactions were considerably liberalized; and

11 . The maximum tariffs rate was reduced from 230 to $80 \%$.

12. Land on lease to the Private Foreign Companies at cheapest rate

13. The reform included the removal of substantial taxation of agriculture, market liberalization and devaluation.

14. The restrictions on grain movements, the quota system of grain delivery (to the parastatal Agricultural Marketing Corporation) imposed on farmers and the system of fixed pricing for farm produce were abolished.
15. The fertilizer market was liberalized, creating a multichannel distribution system.

The overriding objective of the government is to attain fast, broad-based economic development. A development strategy known as the Agricultural DevelopmentLed Industrialization (ADLI) has been formulated to focus on agriculture. The strategy views agriculture as the engine of growth, on account of its potentially superior growth linkages, surplus generation, market creation, and provision of raw materials and foreign exchange. In accordance with its policy of decentralization, the government has brought many of the smaller research centers under the control of regional governments, while those with totaling 10 National research centers were kept under IAR management. Regional research centers are expected to address specific local and regional problems. IAR was also reorganized in 1997 and renamed as EARO (the Ethiopian Agricultural Research Organization). The National Seed Industry Agency (NSIA) and the National Seed Industry Council (NSIC) were established in 1993 to implement the new seed policy which envisages participation of both public and private enterprises in the production and marketing of improved seeds. The National Variety Release Committee (NVRC) has been reorganized and placed under NSIC. NSIA is responsible for quality control and certification of seeds. Within the framework of ADLI, a new system of agricultural extension, known as the Participatory Demonstration and Training Extension System (PADETES) was launched in 1994/95.

The principle of PADETES is to demonstrate to farmers the benefits of a package of inputs, notably balanced and higher rates of fertilizer, improved seeds, pesticides and better cultural practices. Farmers who agree to participate in the new extension system allocate $1 / 2$ ha of land (in some cases $1 / 4$ ha or less) for the demonstration and make a $25-50 \%$ down payment on the inputs used at the time of planting with the balance due after harvest. The farmers manage the plots under a close supervision and advice of extension agents. The operation is assisted by officials in the administration and other government offices. Being at the center of the overall development strategy, PADETES enjoy the full support of the government. Government officials closely follow and assist extension activities. Government authorities coordinate input supply and distribution. The Input Coordination Unit (ICU), organized at local, district, zonal, regional and central levels, consists of representatives from administration, banks, input suppliers and Ministry/ Bureau of Agriculture.

\section{PROPOSED LAND TENURE SYSTEM/LAND REFORMS IN ETHIOPIA}

The land tenure system has a vital role to play in 
catalyzing the change from a subsistence agriculture structure to a commercial cash crop production. Agricultural productivity is closely tied to the land system of a country. Extensive commercial farms boost agricultural production because the size itself considerably reduces production cost and improves productivity at large. Balance of payment sustained a negative balance for quite a number of years. Agricultures outputs, structurally, are not favourably exports items as they are prone to price volatility and supply shocks. Had the agricultural export been semi-processed and/or fully processed commodities, generally the price they command at the global markets would show a significant change.

Three types of strategies can be adopted:

1. Integrating agriculture with industrial sector (agroprocessing).

2. Import-substituting production is also critical in reducing the extremely high imports levels of the economy and hence, in improving trade balance and foreign reserve all together.

3. In general, the structural inefficiency of the nature of the economy itself gave rise to those problems and the only way to correct it is by addressing these inefficiencies.

There are three types of land tenure systems

1. Subsistence properties (land) owned by the farmers in the rural areas and urban dwellers around the towns should be under private ownership and be free to buy or sell at the will of the occupants.

2. On the other hand, the pastoral lands in the peripheral region should be under communal ownership. The socioeconomic conditions of the pastoral communities by themselves suggest common ownership of land.

3. Apart from the above two, the massive landmass in the major cities and unoccupied rural areas should remain under the government control. However, step- by-step this category should be transferred to private ownership in due time.

\section{Technical change and agricultural productivity in Ethiopia}

More than 55 million Ethiopian people live in rural areas as subsistence agriculture is the basis of their lives. Agriculture is in the hands of small scale individual farmers who make use of little agricultural inputs. The peasant sector, which composes of about 7 million smallholder farmers, produces about 97 percent of the total crop output including 98 percent of the coffee production. The major crops grown in the peasant sector include food crops; cereals, pulses, oilseeds; while cotton and sugarcane have however been grown primarily on state farms. Coffee is an export cash crop, which generates about 60 percent of the country's export earnings. The contribution of agriculture to GDP varied between 46 and 58\% between 1980/81 and 1997/97, which still generates $40-45 \%$ of GDP in 2007 . About $85 \%$ of the foreign exchange is also derived from agriculture. Because of new economic policies and strategies and introduction of new extension packages increased use of fertilizer and improved seeds; improvement in crop production was observed in the agricultural sector.

One area in which there has been little change over the years in Ethiopian agriculture is the technology of land preparation. Except for some small areas of the highlands where hoe cultivation is practiced, all land preparation is carried out with oxen pulling the traditional plough. It is believed that the Ethiopians inhabiting the highlands were introduced to animal traction between 1000 and $400 \mathrm{BC}$. The traditional plough, which remained unchanged, requires several passes to prepare land for planting. In most highland areas, some 5 or 6 months of the year are spent on seed-bed preparation, which involves a pair of local zebu oxen pulling the traditional plough. Of the estimated 31 million head of cattle, about 9 to 10 million are used for draught purposes. Apart from taking most of the agricultural labor time and requiring large number of draught animals, the existing technology of land preparation is of little use for turning the stubble and weeds into the soil. The result has been high level of weed infestation, one of the major factors contributing to low yield levels in the country. It should also be added that area expansion was achieved through cultivation of hillsides and areas with steep slopes where erosion poses serious threat to sustainable farming. Land degradation was also exacerbated due to elimination of fallow land and conversion of woodland and forest areas into farmland.

Total area cultivated under major crops has been increasing at the rate of 1.7 per cent per year. Area cultivated under cereals, which comprises 84.2 per cent of major crops in 1998/99, has shown an increasing tendency in the following two years and there after a declining trend in the years 2001/02-2002/03. Generally, the annual average growth rate was marginally below zero $(-0.2 \%)$.

\section{Trends in public spending on agriculture and food security}

Agriculture accounts for the biggest share of the economy. Even though Ethiopia is endowed with good environment and fertile soils for agriculture and agriculture is the only business venture people could pass through to eradicate poverty to-date a strengthened job was not conducted. Hence, focusing on this predominant sector can help combat poverty, since poverty is most severe in the countryside and production 
lags behind fostering insecurity and widespread rural poverty.

However, agriculture is the engine of the country's economic growth; the trends in public spending on this sector during the five years covering the survey did not show that due attention was given. The annual average growth rate for recurrent and capital public budget spending showed a rise of $7 \%$ and a decline of $1.2 \%$, respectively. And the total annual average rate rose by about $1.7 \%$. The share of capital expenditure during the five years ranged between 56.8 and $68.5 \%$ and has shown a declining tendency. The country is ranked 26th out of 40 nations in the sub-Saharan Africa region where its overall score is slightly worse than the regional average, the report says. The top income and corporate tax rates in the country are moderate, and overall tax revenue is not large as a percentage of GDP. Government expenditure is not very high, and labour markets, unlike those in most of Europe and the rest of Africa, are lightly regulated. Ethiopia has failed to score well in international/regional trade. It has also failed to attract foreign direct investment (FDI). The overall freedom to start, operate and close a business in Ethiopia is restricted by national regulatory environment. Total government expenditure, including consumption and transfer payments, are low. In the most recent year, government spending equated $25.2 \%$ of GDP. Despite a decade of privatization, state ownership and management still guide many sectors of the economy. Ethiopia's financial sector is small and significantly influenced by the government. The National Bank is not independent; the government strongly influences lending, controls interest rates, and owns the largest Commercial Bank of Ethiopia, which accounts for two-thirds of outstanding credit. The data show that Ethiopia's foreign exchange reserves are running low, making it more difficult for domestic investors to secure foreign currencies needed to import key materials and equipment.

Ethiopia has 74 million hectares of land that is said to be suitable for agriculture out of its total area of 111.5 million hectares. However, less than 15 million hectares is currently in use. Foreign investors use their land at a time when their people face the spectre of mass starvation. About 10 percent of the more than 80 million people who live in Ethiopia suffer from chronic food shortages. This year, because of poor rains, the U.N. World Food Programme warns that much of East Africa faces the threat of a famine, potentially the worst in almost two decades. Traditionally, the model for feeding the hungry in Africa has involved shipping in surpluses from the rest of the world in times of emergency, but governments that are trying to attract investment say that the new farms could provide a lasting, no charitable solution. Ethiopia might seem an unlikely hotbed of agricultural investment. To most of the world, the country is defined by images of famine: about a million people died there during the drought of the mid-1980s, and today about four times that depend on emergency food aid. According to the World Bank, as much as three-quarter of Ethiopia's arable land is not under cultivation, and agronomists say that with substantial capital expenditure, much of it could become bountiful.

\section{Foreign Investment in agriculture}

FDI in the agriculture sector in Ethiopia exhibited accelerated growth in recent years. A report by Ecofair Trade Dialogue (2009) based on data from Federal Investment Bureau of Ethiopia shows that in the last three years, FDI inflow to Ethiopia has been growing by USD 3,500 million each year. In sub-Saharan Africa, along with Kenya, Madagascar and the Seychelles, Ethiopia is a very attractive destination for FDI. Before 2005, FDI was mainly concentrated on implementation and operation investment. In last three years, however, such kind of investment declined and pre-implementation investment is rising. Pre-implementation category of investment refers to one for which up to now land, machines, building materials have been bought.

\section{Three main reasons for a shift in FDI inflow}

1. One of the reasons is a significant change in the exchange rate of the main investors, leading to a depreciation of the Ethiopian birr in comparison to currencies of the investors.

2. The other reason is the world food crisis which motivated grabbing of natural resources to safely ensure food security in investor's nations.

3 . The last reason is immensely investor friendly environment in Ethiopia.

The main investor countries are the EU countries (Germany, Netherlands, Italy, Britain, Greece, Cyprus, Ireland, Norway, Finland, Sweden, Austria, Ukraine, Denmark, Chez Republic, France and Belgium), India, Israel, Saudi Arabia and USA. Between 2000 and 2008 the EU invested about $21.22 \%$ of FDI in Ethiopia while India, Israel, Saudi Arabia and USA invested 32.43, 7.18, 3.1 and $11.54 \%$, respectively. EU is mainly engaged in the agribusiness sectors like meat production, biofuel and horticulture. India takes part in the horticulture and sugar production sector. Israel invests on horticulture, biofuel and vegetable production. Saudi Arabia is mainly focusing on meat production and bio-fuels while the USA is investing on meat production and horticulture. Most of the FDI inflow goes to Oromia, Amhara and SNNP states in that order while the Tigray State investors mainly focus on the meat production sector. Oromia is the major magnet of FDI because of its favourable climatic conditions for horticulture and vegetable production, and partly because of its proximity for the capital. 
Proximity to the capital offers significant benefits in having better access to international flights. The investment policy allows sole proprietor or joint ventures with domestic investors, requires minimum investment capital based on the investor type. For example, this minimum investment requirement could be exempted if the investment export is more than $75 \%$ of its output and / or reinvests its profit. Agriculture sector investment is largely free of restrictions and regulations. However, there are some sectors that are reserved for domestic investors.

The Sustainable Land Management project of the Ministry of Agriculture and Rural Development is expecting to receive an aid inflow of 38 million dollars from Finnish and German sources in 2010 (Merga, 2009). The project, which is owned by MoARD was officially launched in October 2008 with a budget of 55 million dollars, of which 8.8 million dollars was provided by the government while the rest was contributed by the World Bank, Global Environment Facility, and German Technical Cooperation. The German Bank for Reconstruction and the Govern-ment of Finland will offer a combined sum of 38 million dollars before the end of 2010 for projects in different areas, like Amhara, Oromia and Tigray, while that of the Finland Government will be for the implementation of the land in Gambella, SNNP, Benishangul, Gumuz. Over 700,000 people on 500,000 ht of land are expected to benefit from the projects (Merga, 2009).

In a country like Ethiopia, farmers put in backbreaking effort, but they yield about a third as much wheat per acre as do Europe or Chile (Andrew, 2009). Ethiopia, like all of Africa, is full of such opportunities, which is one reason the World Bank says that investing in agriculture is one of the most effective ways to speed economic development on the continent. Yet agriculture has historically been a tiny item in foreign aid budgets. For years, governments, private foundations and donor institutions like the World Bank have been urging African governments to fill the spending gap with private investment. Now, at the very moment a world food crisis has come along, creating the perhaps fleeting possibility of an influx of capital into African agriculture, some of the same organizations are sending conflicting messages. The Food and Agriculture Organisation, for instance, cosponsored a report calling for a major expansion of commercial agriculture in Africa, but the organisation's Director General has simultaneously been warning of the "neo-colonial" dangers of land deals (Andrew, 2009).

\section{The dirt-cheap annual rate of land}

FDI in the agriculture sector in Ethiopia is particularly appealing due to the existing encouraging investment policy, lower land lease prices, cheap labour and cheap production cost. The lease period could be 20 to 45 years and its price is determined according to each region land regulations. The lease price could also vary depending on type of investment, location of the land and accessibility to roads. In Oromia, for example, foreign investors are permitted to employ foreign nationals and hire a foreign national at top management post without any prior approval of Ethiopian Investment Agency. FDI investors who are involved in export could get loan from the Development Bank of Ethiopia and other countries, and allow to pay back the principal and interest in convertible foreign currencies. Investors in the agriculture sectors are exempted from the payment of custom duties and other taxes levied on imports of all capital goods and construction materials necessary for establishment of new projects and for expansion or upgrading of existing projects. The exemption on capital goods and construction materials is only applicable if the investment is superior in quality and quantity in comparison to those domestically produced. Investors engaged in agroprocessing and producing agricultural products are exempted from paying income tax for a period of two to eight years. It gives high encouragement to export based agro-processing and agricultural products by lifting all restrictions and regulations, offering tax exemption from capital goods and construction materials, and providing loan and income tax exemption for period of 2 to 8 years.

One focus of agricultural investment in Ethiopia is the region of Gambella, near the border with Sudan. The World Bank says it has more than four million acres of irrigable land. Since the world food crisis, Meles, a former Marxist rebel who has turned into a champion of private capital, has publicly said he is "very eager" to attract foreign farm investors by offering them what the government describes as "virgin land." An Ethiopian agriculture ministry official recently told Reuters that he has identified more than seven million acres. The government plans to lease half of it before the next harvest, at the dirt-cheap annual rate of around 50 cents per acre. The government's pliant attitude, along with Ethiopia's convenient location, has made it an ideal target for Middle Eastern investors like Al-Amoudi. The Saudi delegation, which included Abdullah bin Ahmed Zainal Alireza, minister of Commerce and Industry and three other Saudi Ministers, had representatives from 50 large Saudi companies. On the other hand, from seven African countries, including Ethiopian Prime Minister, Rwanda, Djibouti and Somali President, Kenya, Tanzania, Uganda's top government officials representatives were represented at the exhibition. A newly formed Al-Amoudi company, Saudi Star Agricultural Development, announced its plans to obtain the rights to more than a million acres in the apparent hope of capitalizing on the Saudi government's initiative to subsidize overseas staple crop production. At a pilot site in the west of the country, he is already cultivating rice. In the Rift Valley region, another subsidiary is starting to grow fruits and vegetables for export to the Persian Gulf. The 2000 acre 
enterprise currently produces food for the local market, but there were plans to irrigate with water from the lake, and to shift the focus to exports. A couple of workers get only nine Birr or around 75 (dollar) cents each day. AlAmoudi's plans raise a recurring question surrounding investment in food production: who will reap the benefits? (Andrew, 2009).

Karaturi Global, an Indian company with agricultural interest in the Gambella Regional State of Ethiopia, requested, in early November, that the Ministry of Water Resources authorized it to use the Baro River to irrigate crops for its intended agricultural development project. The company had applied for 300,000 hectors land in Ethiopia, but the Investors Support Directorate at the Ministry of Agriculture and Rural Development, which handles large tracts of land for regional states, granted it 40,000 hectors, agreeing in principle to give it the $300,000 \mathrm{ht}$ it requested depending on its initial performance. The master plan for the Baro Akobo River Basin, prepared by MoARD in 1997, indicated that the water in the basin could irrigate $50,900 \mathrm{ht}$ of land. The estimated budget to develop the water resources in the area, as indicated in the master plan, was 378.4 million dollars. This land is to be suitable for cotton, sugarcane, maize and sorghum, as well as a number of other grains. This company has so far taken the largest plot of land. The company has allocated 250 million dollars for its Gambella project, which it says will be its largest investment in Ethiopia. It says that the company is ready to grow maize, rice, sugarcane and palm tree products on $11,000 \mathrm{ht}$. The company says that its total investments could reach 4.3 billion Birr, more than half of it going to agriculture, including horticulture. It also plans to invest in the metal industry. The Baro River, a tributary of the White Nile, serves local communities for transport and fishing in addition to regulation Gambella's temperature. It is also the only navigable waterway in Ethiopia and was once used as a port due to its access to the Nile. Sai Ramakrishna Karuturi, head of an Indian commercial farming company says, "It is emerald green, the whole place is fertile and they have only 200,000 people down there. Earlier this year, Karuturi signed an agreement with the government to lease close to 800,000 acres on which he will grow rice, wheat and sugarcane, among other crops. Karuturi told me he does not have to export the food to make money; there is plenty of profit potential in the East African market. He has flown in John Deere tractors, agricultural experts from Texas $A$ and $M$ and commercial farmers from Mississippi to help him get things going. He says he is raising 100 million dollars in capital from private equity firms for the first phase of the project, which he estimates will ultimately cost well over a billion dollars (Wudineh, 2009).

According to the International Institute for Environment and Development; as of earlier this year, the Ethiopian government had approved deals totaling around 1.5 million acres, while the country's investment agency reports that it has approved 815 foreign financed agricultural projects since 2007, nearly doubling the number registered in the entire previous decade. The South Korean conglomerate Daewoo Logistics had signed an agreement to take over about half of Madagascar's arable land, paying nothing, with the intention of growing corn and palm oil for export. Popular protests broke out, helping to mobilize opposition to Madagascar's already unpopular president, who was overthrown in a coup in March 2009. Development economists and African governments say that if a country like Ethiopia is ever going to feed itself, let alone wean itself from foreign aid, which totaled 2.4 billion dollars in 2007, it will have to find some way of increasing the productivity of its agriculture (Andrew, 2009).

\section{DEVELOPMENT DEBATE WITH ROMANTICISM}

Paul Collier of Oxford University, an influential voice on issues of world poverty, published a provocative article in Foreign Affairs in which he argued that a "middle and upper-class love affairs with peasant agriculture" has clouded the African development debate with "romanticism." Approvingly citing the example of Brazil where masses of indigenous landholders were displaced in favour of large-scale farms (Prabhakar, 2010). Collier concluded that "to ignore commercial agriculture as a force for rural development and enhanced food supply is surely ideological". In Ethiopia, Al-Amoudi and other foreign agricultural investors are putting Collier's theory into practice. Near the Southern town of Awassa, in the shadow of a soaring Rift Valley escarpment, sits a field of waving corn and a complex of domed greenhouse, looking pristine and alien against the natural backdrop. On an overcast July morning, dozens of labourers were at work preparing the ground for one of Al-Amoudi's latest enterprises: a commercial vegetable farm. Jan Prins, managing director of the subsidiary company that is running the venture for Al-Amoudi, originally from the Netherlands, said that Ethiopia was arid but was surprised to learn when he came to the country that much of it was fertile, with diverse microclimates. The Awassa farm is one of four that Prins is getting up and running. Using computerized irrigation system, the farms will grow tomatoes, peppers, broccoli, melons and other fresh produce, the vast majority of it to be shipped to Saudi Arabia and Dubai. He assumed to expand into growing other crops, like wheat and barley, the latter of which can be used to feed camels.

"A variety of factors-some transitory, like the spike in food prices, and others intractable, like global population growth and water scarcityhave created a market for farmland, as rich but agricultural resource deprived nations in the Middle East, Asia and elsewhere seek to 
outsource their food production to places where fields are cheap and abundant". Because much of the world's arable land is already in usealmost $90 \%$, according to one estimate, taking out forests and fragile ecosystems-the search has led to the countries least touched by development, those in Africa (Andrew, 2009).

According to a recent study by the World Bank and the United nations Food and Agriculture Organization, one of the earth's last large reserves of underused land is the billion acre Guinea Savannah zone, a crescent-shaped swath that runs east across Africa all the way to Ethiopia and southward to Congo and Angola. Foreign investorssome of them representing governments, some of them private interests- are promising to construct infrastructure, bring new technologies, create jobs and boost the productivity of underused land so that it not only feeds overseas markets but also feeds more Africans. More than a third of the continent's population is malnourished. They have found that impoverished governments are often only too welcoming, offering land at giveaway prices. A few transactions have received significant publicity, like Kenya's deal to lease nearly 40 , 468 hectares to the Qatari government in return for financing a new port, or South Korea's agreement to develop almost 1,000 square kilometers in Tanzania. But many other land deals, of near-unprecedented size, have been sealed with little fanfare.

Investors who are taking part in the land rush say they are confronting a primal fear, a situation in which food is unavailable at any price. Over the 30 years between the mid-1970s and the middle of this decade, grain supplies soared and prices fell by about half, steady trends that led many experts to believe that there was no limit to humanity's capacity to feed itself. But in 2006, the situation reversed, in concert with a wider commodities boom. Food prices increased slightly that year rose by a quarter in 2007 and skyrocketed in 2008. Surplus producing countries like Argentina and Vietnam worried about feeding their own populations, placed restrictions on exports. American people, if they noticed the food crisis at all, saw it in modestly inflated supermarket bills, especially for meat and dairy products. But to many import-dependent countries like in the Middle East, South Korea and Japan- the spectre of hyperinflation and hoarding presented an existential threat. When some governments stop exporting rice or wheat, it becomes a real, serious problem for people that do not have full "self-sufficiency," said Al Arabi Mohammed Hamdi, an economic adviser to the Arab Authority for Agricultural Investment and Development. Hamdi said that the only way to assure food security is to control the means of production. Hamdi's agency, which coordinates investments on behalf of 20 member states, has recently announced several projects, including a tentative 250 million dollars joint- venture with two private companies, which is slated to receive heavy subsidies from a Saudi programme called the King Abdullah Initiative for Saudi Agricultural Investment Abroad. The main fields of investment for the project would most likely be Sudan and Ethiopia, countries with favourable climates that are situated just across the Red Sea. Another partner, Mansour bin Zayed Al Nahyan, a billionaire member of the royal family of the emirate of Abu Dhabi, has shown an interest in acquiring land in Sudan and Eritrea. Over time, Al-Amoudi, a Saudi Arabia-based oil and construction billionaire and one of the world's 50 richest people, who was born in Ethiopia and maintains a close relationship with the Ethiopian Prime Minister Meles Zenawi's autocratic regime, has used his fortune and political ties to amass control over large portions of Ethiopia's private sector, including mines, hotels and plantations on which he grows tea, coffee, rubber and jatropha, a plant that has enormous promise as a biofuel. Since the global price spike, he has been getting into the newly lucrative world of food trade.

\section{The Saudis' strategy to ensure food supply}

The Saudis, rich in oil money but poor in arable land, were grouping for a strategy to ensure that they could continue to meet the appetites of a growing population. There are basically two ways to increase the supply of food: find new fields to plant or invent ways to multiply what existing ones yield. Robert Zeigler, an eminent American botanist, runs the International Rice Research Institute, which is devoted to the latter course-employing science to expand the size of harvests. During the Green Revolution of the 1960s, the institute's laboratory developed "miracle rice," a high yielding strain that has been credited with saving millions of people from famine. Zeigler went to Saudi Arabia hoping that the wealthy kingdom might offer money for the basic research that leads to such technological breakthroughs. Instead, to his surprise, he discovered that the Saudis wanted to attack the problem from the opposite direction. They were looking for land. In a series of meetings, Saudi government officials, bankers and agribusiness executives told an institute delegation led by Zeigler that they intended to spend billions of dollars to establish plantations to produce rice and other staple crops in African nations like Mali, Senegal, Sudan, and Ethiopia.

One important and the best example may be suitable for Ethiopia. The government of Qatar, in addressing its food security concerns, has chosen to concentrate on investing in existing agribusiness rather than just acquiring land for large-scale farming. That is just one of many ways to invest in farming without removing the African farmers. It is a cooperative scheme under which a group of around 300 Ethiopians, working plots of 4-10 acres, was getting into export agriculture. During the Ethiopian winter, they grew green beans for the Dutch 
market. The rest of the year they cultivated corn and other crops for local consumption. The land had been irrigated with the help of a non-profit organization and an Ethiopian commercial farmer named Tsegaye Abebe, who brought all the produce to market. The agricultural products the strategy should consider include vegetables, fruits, silk production, dairy and poultry, as well as wheat, maize and barley. The agriculture sector includes features like irrigated year-round production, small-scale processing of dairy products, vegetables and providing shorter marketing chains for consumers, and producers may benefit through technical assistance, drip kits, poultry, and fruit trees and work in group gardens.

\section{Ethiopian SMEs Performance}

There are more than 73000 SMEs established in Ethiopia by the year 2007/08; they have created employment opportunities for 551,075 individuals, according to the annual progress report from Ministry of Works and Urban Development. What went wrong with SMEs development strategy that makes its achievements so modest?

A range of factors, from the lack of political commitment to the condemnatory popular attitude, are challenging the survival of Ethiopian SMEs. The current SMEs movement in Ethiopia was embraced in the urban development policy of the incumbent, which is one of the pillars of the plan for Accelerated and Sustained Development to End Poverty. The main objectives of the strategy were reducing urban unemployment, helping to realize the progressive shift from agriculture to industrial development and incubating domestic enterprise development. The strategy was found very attractive by the urban unemployed, especially the youths. Provided that technical and vocational education and training was gaining momentum, SMEs were conceived to be the way to transform technical skills into business by many. Yet, the strategy was short-sighted in terms of putting clear tactics in place to link the SMEs with the biggest industries and help them to climb up the ladder of enterprise development. Besides, it was not accompanied by longterm market analysis, either domestically or internationally.

On the technical side, the SMEs development strategy has many holes, which could not be filled with the quick fixes made at different occasions over the years. The biggest of the holes is the failure to create the link between SMEs and bigger industries. In relation to this, failure to draw a clear strategy for enterprises development and transformation has also been widening added significantly to the holes.

Another important technical snag that Ethiopian SMEs face is the absence of market information. That has led some of them to produce non-tradable and sub-standard goods. Add to this is lack of planning and management capacity, which often causes them to overproduce goods.
Just as what the ECX has made to synchronies agricultural market, it should be putting in place a clear strategy to synchronize SMEs with domestic as well as international markets. In furthering the market synchronization, the government could also help SMEs get cheap credit by negotiating with both private and public financial institutions. Diversification of product types should also be given attention by the government and the enterprises alike. It is only then that the holes of the SMEs development strategy could be filled, thereby creating a smooth playing field for them. For example, popular international brands like Nike and Adidas work in partnership with many SMEs. The government has to extend a helping hand to SMEs by inspecting the quality of their products. There is need to learn from the Chinese experience in creating inter-industrial linkage and assisting SMEs to transform themselves into bigger business ventures.

\section{Conclusion}

What should the country like Ethiopia do? The available evidence indicates that the rate of economic growth over the last three decades has been stagnant. Agriculture is still the mainstay of the economy accounting for about 50 percent of GDP, 85 percent of the labour force and 90 percent of export earnings. The industrial sector on average contributes only 10-12 percent of GDP. The service sector grew moderately but with large variations in the performance of the sub-sector. During the period of the Derg regime the share of agriculture was 53 percent in GDP and now the present regime, it is 51 percent. Despite massive efforts by the present EPRDF government to improve the sector's performance, agricultural production did not show a significant improvement over the Marxist regime. Industrial sector's contribution to the country's GDP on the average between 1980/81 to $1990 / 91$ was $12.2 \%$; it remained static over the period $1992 / 93$ to $2004-05$ with average of $10.6 \%$ and $12.8 \%$ in 2006-07 of GDP.

Ethiopia's current year performance is overall lower than last year. The country is ranked 26 out of 40 nations in sub-Saharan Africa. The data show that Ethiopia's foreign exchange reserves are running low, making it more difficult for domestic investors to secure foreign currencies needed to import key materials and equipment. Too small landholdings, poor agricultural practices, lack of potable water and other factors contribute to a vicious cycle of deteriorating health and environments-and to increasing poverty. The landless, refugees, the displaced due to war, and demobilized soldiers in poverty are included; there are a total of about 27 million people out of a population of about 52 million $(52 \%)$ living in chronic and transitory poverty in urban and rural areas. Income inequality is reported to be unusually high, inequality in urban and rural areas increased sharply, during the time of economic recovery. This 
shows that economic growth alone cannot solve the problem of poverty. Although it is a mosaic of various diverse groups, the Ethiopian state did not incorporate these groups into the political process and many thought there was national oppression, the state serving only certain part of the society-principally the ruling class.

\section{People -centered development strategy under South- south cooperation}

It is possible to create a viable large-scale networked production system of the rural poor based on local resources, capabilities and markets through appropriate organizational and $S$ and $T$ efforts. This can be done if the rural poor are organized to strengthen their inter links and advance the local economy by encouraging local value addition through linking of primary and secondary production and through the technological up gradation of existing occupations. There should avoid mutual competition among small producers and for superior access to resources and markets, and to technology transfer to organized poor for area based multi-sectoral large-scale production systems.

Under competitive conditions the self-employed small producers have not only to come together for access to resources, but also have to emerge as a multi-sectoral collective of producers, co-operating in production. Since economies of scale are required to overcome adverse competition, rural poor will have to be consciously networked and technologically advanced in a mutually complementing way. Rural poor will have to pool the resources and capabilities for raising the scale and scope of their collective production organization. This change in the scale and scope can alone allow the participating members to lower the barriers facing them in the creation and adoption of more sophisticated and improved technologies which can make their production more competitive than before in the local markets. The local economy has already been existing. In the local economy the range of occupations engaging the rural poor is wide and varied. It includes agriculture labour, small/ marginalcultivators, hides and skins occupations ranging over flaying, carcass utilization tanning, and product making; cloth weaving, dyeing and printing; fibre collection/ extraction, basket and mat weaving; animal husbandry, poultry, fishing, toddy tapping, etc and allied secondary processing like food processing; carpentry, pottery, and masonry and other engineering-artisans, or handicraft occupations and manual haulage. The networks of group enterprises comprising rural poor can be built around the principle of worker co-operatives, that is, worker ownership, collective appropriation of surplus and full participation in decision making. It is necessary to understand that the local economy-led by small-medium scale industries cannot compete without protection by the state.
China, India and Brazil have provided a platform for increased exports and the inception of a model of cooperation based on trade, investment, and technology transfer, rather than "aid." In April 2008, the first ever India-Africa Forum Summit (IAFS) was held in New Delhi, India (Pasricha, 2008). The 3-day (19-21 March, 2008) Conclave was attended by the Ministers of Ethiopia including Angola, Botswana, Burkina Faszo, Chad, Comoros, Cote D'Ivore, D.R. Congo, Republic of Congo, Djibouti, Ghana, Madagascar, Malawi, Mali, Morocco, Niger, Nigeria, Senegal, South Africa, Swaziland, Sudan, Tanzania, Uganda, Zambia and Zimbabwe. "Project partnership is a key in this effort. The main goals and objectives are to achieve poverty alleviation, human development and economic growth can be addressed in part through project partnerships." The ITEC programme was launched in 1964 as one of the important pillars of South-south cooperation focusing on capacity building through short-medium term courses in India and deputation of Indian experts. Fellowships given to Ethiopia have steadily registered 150 percent increase and gave to 90 Ethiopian scholars, making Ethiopia the third in Africa (Bigsten, 2003).

India keenly anticipates a deeper and closer engagement with Ethiopia and is eager to work together for greater mutual prosperity. Agriculture and food processing are key sectors for cooperation, as both sides are prone to food shortages, lack of diversification in crops, and low agricultural productivity. India's strategic global engagements depend much on its strong relations with Africa. India's exports to Africa during 2006-07 stood at US $\$ 8.4$ billion, while imports aggregated US $\$ 11.4$ billion, having almost doubled since previous year. Exports to Africa are regionally diversified with East, Southern and West Africa accounting for US \$ 2.5-3 billion each. India needs to expand and diversify the import basket from the regional blocks like SACU, COMESA, SADC, and EAC.

China-Africa trade alone increased from $\$ 10$ billion in 2000 to $\$ 107$ billion in 2008 and billions of dollars are being invested in oil production, mining, transportation, electricity generation and transmission, telecommunications and other infrastructure. These developments have combined to improve African countries' macroeconomic performance dramatically. Cooperation in trade, finance, science and technology, civil aviation, culture, sports, and tourism has enhanced the development of China-Africa new type of strategic partnership," to promote balanced, coordinated and sustainable development of the regional as well as global economy. The Beijing summit of the Forum on China-Africa Cooperation (FOCAC) that was held in 2006 has become a milestone by this historical event, the relationship between two regions was helping to fight poverty in Africa and that the continent needed cooperation without political conditions ${ }^{1}$. The largest

${ }^{1}$ Seyoum Mesfin, Ethiopian Foreign Minister, Beijing summit, 2006. 
China-Africa gathering (from nearly 50 African countries' delegates) descended to enhance South-South cooperation on the basis of mutual benefits and counter the traditional establishment of unequal exchange and exploitative trade deals combined with $\mathrm{aid}^{2}$ by Europe, Japan and the United States.

\section{REFERENCES}

Andrew $R$ (2009). Is There Such a Thing as Agro-Imperialism? http://www.nytimes.com/2009/11/22/magazine/22landt.html?pagewanted=all\& r=0. Published: November 16, 2009.

Bigsten A (2003). "Selecting Priorities for Poverty Reduction and Human Development: The Case of Ethiopia in Addison, T. (ed.), From Conflict to Reconstruction in Africa, Oxford University Press, Oxford.

Devereux S (2010). Food Insecurity in Ethiopia. A discussion paper for DFID. content/uploads/2010/03/FoodSecEthiopia4.pdf

Merga Y (2009). Germans, Fins Fund Land Sustainability. Volume 10, Number 504 Published On Dec 27, 2009. http://www.addisfortune.com/Vol\%2010\%20No\%20504\%20Archive/G ermans\%20Fins\%20Fund\%20Land\%20Sustainability.htm
Pasricha A (2008). "India-Africa Summit Pledges Close Partnership". VOA News (Voice of America). Retrieved January 3, 2009.

Prabhakar AC (2003). South-South Cooperation: A Case Study of India and East Africa. PhD Thesis. JNU. New Delhi.

Sen A (1981). Poverty and Famines: An Essay on Entitlements and Deprivation. Clarendon Press. Oxford.

Wudineh Z (2009). Indian Investors Enquire to Irrigate with Baro River. http://www.addisfortune.com/Vol\%2010\%20No\%20499\%20Archive/l ndian\%20Investors\%20Enquire\%20to\%20Irrigate\%20with\%20Baro\% 20River.htm. Volume 10, Number 499 Published On Nov 22, 2009

\footnotetext{
${ }^{2}$ See, Elizabeth C. Economy, CFR's senior fellow and director for Asia studies
} 